\title{
Deep sequencing of the TCR $\beta$ repertoire reveals T cell clonal expansion is associated with HTLV-1 proviral load in HAM/TSP patients
}

\author{
Alessandra de Paula A Sousa ${ }^{1}$, Kory R Johnson², Joan Ohayon ${ }^{1}$, Jun Zhu $^{3}$, Paolo Muraro ${ }^{4}$, Steven Jacobson ${ }^{\text {* }}$ \\ From 17th International Conference on Human Retroviruses: HTLV and Related Viruses \\ Trois Ilets, Martinique. 18-21 June 2015
}

HTLV-1 associated myelopathy/tropical spastic paraparesis (HAM/TSP) is associated with a chronic inflammatory central nervous system in which the host immune response against HTLV-1 infection is considered immunopathogenic. We have applied a new unbiased deep sequencing method of TCR repertoire to accurately measure the diversity and degree of clonal expansion of peripheral circulating T-cells in patients with HAM/TSP compared to age, gender, and ethnicity matched healthy controls. TCR libraries were generated using 5'rapid amplification of cDNA ends to amplify the V-D-J genes of unsorted T-cells obtained from peripheral blood. Over 100 million reads were analyzed using MiGec software (Shugay, et al., Nat Methods. 2014 Jun;11(6):653-5), that align and match the human TCR $\beta$-chain nucleotide sequences through IMGT database. T-cell clonotypes with high-quality CDR3 sequence were selected by a molecular identifier PCR strategy, which allowed for filtering PCR errors and correct for artificial sequences generated on a HiSeq 2000 Illumina system platform. By calculating the coefficient of variation of our dataset we considered clonal expansion as those unique TCR clonotypes showing reads $>8$. While we did not observe any significant statistical differences of the number of single clones (clonotypes with 1 read, $\mathrm{P}=0.62$ ) between HAM/ TSP patients and healthy controls groups, by contrast, a higher clonal expansion of the T-cell repertoire was observed in HAM/TSP patients when compared to healthy controls (unpaired parametric $\mathrm{T}$-test with $\mathrm{P}=$ 0.026). Interestingly, this clonal expansion of the HAM/ TSP TCR repertoire correlated with the HTLV-I provirus

\footnotetext{
* Correspondence: jacobsons@ninds.nih.gov

${ }^{1}$ Neuroimmunology Branch, Viral Immunology Section, National Institute of Neurological Disorders and Stroke, NIH, Bethesda, Maryland, USA Full list of author information is available at the end of the article
}

load (as defined by digital PCR quantification of the HTLV-I tax gene) $(r=0.64, P=0.008)$. Our findings strongly suggest that in this chronic neurological disorder, a strong dysregulated $\mathrm{T}$-cell response may be driven by HTLV-I and that strategies to decrease virus may be of clinical benefit.

\section{Authors' details}

${ }^{1}$ Neuroimmunology Branch, Viral Immunology Section, National Institute of Neurological Disorders and Stroke, NIH, Bethesda, Maryland, USA.

${ }^{2}$ Bioinformatics Section, National Institute of Neurological Disorders and Stroke, NIH, Bethesda, Maryland, USA. ${ }^{3}$ Systems Biology Center, National Heart Lung and Blood Institute, Bethesda, Maryland, USA. ${ }^{4}$ Division of Brain Sciences, Faculty of Medicine, Imperial College London, UK.

Published: 28 August 2015

doi:10.1186/1742-4690-12-S1-021

Cite this article as: Sousa et al:: Deep sequencing of the TCR $\beta$ repertoire reveals T cell clonal expansion is associated with HTLV-1 proviral load in HAM/TSP patients. Retrovirology 2015 12(Suppl 1):O21.

Submit your next manuscript to BioMed Central and take full advantage of:

- Convenient online submission

- Thorough peer review

- No space constraints or color figure charges

- Immediate publication on acceptance

- Inclusion in PubMed, CAS, Scopus and Google Scholar

- Research which is freely available for redistribution Submit your manuscript at
www.biomedcentral.com/submit C BioMed Central 